\title{
Analisis Pengaruh Bauran Pemasaran Terhadap Keputusan Pembelian Gas CNG Untuk Kendaraan BBG di Kota Palembang
}

\author{
Reza Helfani \\ Universitas Kader Bangsa
}

\begin{abstract}
ABSTRAK
Penelitian ini bertujuan untuk mengetahui besarnya pengaruh bauran pemasaran terhadap keputusan pembelian gas CNG untuk kendaraan BBG di Kota Palembang, dan untuk mengetahui variabel mana yang dominan dalam mempengaruhinya. Hasil penelitian ini menunjukan bahwa secara keseluruhan variabel bauran pemasaran mempengaruhi keputusan pembelian, dengan nilai variabel produk sebesar 17.9\%, variabel Harga sebesar 19,7\%, variabel Saluran Distribusi sebesar 34,4\% dan varabel Promosi sebesar 32.5\%. Dari ke empat variabel Bauran Pemasaran secara keseluuhan mempengaruhi keputusan pembelian dengan nilai korelasi $68.5 \%$. Secara keseluruhan variabel Bauran Pemasaran mempengaruhi keputusan pembelian, tetapi variabel Saluran Distribusi yang paling besar mempengaruhi konsumen dalam memutuskan pembelian. Ini menunjukan keinginan konsumen dalam menggunakan gas CNG sangat dipengaruhi oleh letak SPBG. Semakin banyak lokasi SPBG maka peminat kendaraan yang menggunakan BBG akan tinggi
\end{abstract}

\section{Kata Kunci : Bauran Pemasaran, Keputusan Pembeli}

\section{Pendahuluan}

Kegiatan perekonomian dan perindustrian diIndonesia saat ini semakin berkembang. Banyak kegiatan - kegiatan ekonomi yang memberikan devisa atau pendapatan Negara, salah satunya kegitan industrinya dibidang minyak dan gas bumi (migas). Sektor migas merupakan sektor penting dalam pembangunan nasional baik dalam hal pemenuhan kebutuhan energi, bahan baku industri ataupun sebagai devisa Negara. Dalam menyelenggarakan kegiatan usaha disektor migas, perusahaan atau investor harus bertujuan mengembangkan perusahaan yang mandiri, andal, transparan, berdaya saing, efisiensi dan berwawasan lingkungan, serta mendorong perkembangan potensi dan peranan nasional, sehingga mampu mendukung kesinambungan pembangunan nasional guna mewujudkan peningkatan kemakmuran dan kesejahteraan rakyat indonesia, maka pemerintah menetapkan undang-undang nomor 22 tahun 2001 tentang minyak dan gas bumi. Ini memberikan dasar hukum bagaimana perusahaan mengelola sumber energi terutama di sektor migas.

Salah satu pemanfaatan gas alam untuk pengembangan infrastruktur, dengan cara mensubsitusikan penggunaan bahan bakar minyak (BBM) pada sektor transportasi darat dengan istilah Natural Gas for Vehicle (NGV), dengan pengembangan teknologi tersebut menggunakan Compress Natural Gas (CNG) dan Liquefied Natural Gas (LNG) sebagai bahan bakar pengganti BBM. Di Indonesia penggunaan (LNG) sebagai bahan bakar kendaraan, untuk saat ini belum dapat di jalankan, tetapi untuk bahan bakar (CNG) beberapa Provinsi di Indonesia telah menggunakannya. Di kala perekonomian di Indonesia semakin menurun, membuat kebutuhan pokok rakyat semakin mahal, ini salah satu solusi untuk masyarakat mengembangkan suatu inovasi yang memberikan dampak positif untuk masa depannya. Di kota Palembang pengenalaan akan pensubsitusian BBM ke BBG diperkenalkan pertama kali oleh PT CNG Hilir Raya pada tahun 2009 yang diresmikan oleh Pemerintah Sumatera Selatan dan Pemerintah Kota Palembang. Dalam memperkenalkan teknologi ini, PT. CNG Hilir Raya bekerja sama dengan Perusahaan Daerah Pertambangan dan Energi, serta pemerintah Kota Palembang dan Provinsi Sumatera Selatan untuk memberikan serta mendistribusikan alat Konversi (Converter Kit) BBM ke BBG secara gratis kepada pihak pemerintah kota palembang dan provinsi, para pelaku bisnis di transportasi darat, pemilik Angkutan kota, dan lainnya Dengan latar belakang tersebut, penulis berkeinginan 
meneliti faktor-faktor yang mempengaruhi pemilik kendaraan untuk menggunakan BBG di kota Palembang.

\section{TINJAUAN PUSTAKA}

Pemasaran itu bukan hanya kegiatan menjual dan membeli saja, tetapi pemasaran memiliki pengertian yang lebih luas. Pemasaran bukan hanya kegiatan menjual barang atau jasa saja tetapi juga mencakup bagaimana barang tersebut sampai kepada konsumen dan konsumen merasa puas dengan barang yang telah dibelinya. Dengan adanya pemasaran yang baik di dalam perusahaan maka diharapkan akan meningkatkan omset penjualan barang atau jasa tersebut sehingga dapat meningkatkan laba yang dihasilkan oleh perusahaan.

Pengertian pemasaran menurut Kotler $(2008 ; 10)$, adalah suatu proses sosial dan manajerial dan di dalamnya individu dan kelompok mendapatkan apa yang mereka butuhkan dan inginkan dengan menciptakan, menawarkan, dan mempertukarkan produk yang bernilai dengan pihak lain.

Keagen, waren J (2009:4) menjelaskan dalam perkembangannya pemasaran sebagai tambahan dari sekedar konsep dan filosopi, adalah kumpulankegiatan dan proses bisnis, Aktivitas empat P (product, Price, Place, dan Promosi) dapat diperluas menjadi lima $\mathrm{P}$ dengan menanmbahkan Probe (riset). Proses manajemen pemasaran adalah kewajiban untuk menfokuskan sumber daya dan sasaran organisasi atas peluang yang ada didalam lingkungan.

Produk merupakan elemen yang paling mendasar dan penting dari bauran pemasaran (marketing mix). Karena dengan adanya produk perusahaan dapat menentukan harga yang pantas, saluran distribusi yang tepat, serta media yang tepat untuk mengomunikasikannya. Jika tidak ada produk maka kegiatan pemasaran tidak akan berjalan karena semua kegiatan pemasaran digunakan untuk menunjang gerakan produk

Setiap Produk yang ada dipasar dapat diamati dalam tiga jenjang M. Suyanto ( 2007 : 108 ) yaitu:

1. Inti Produk

Manfaat hakiki yang benar-benar dibeli oleh pembeli

2. Wujud Produk

Ciri, gaya, mutu, merek dan kemasan yang membentuk suatu produk.
3. Produk yang disempurnakan

\subsection{Harga}

Harga mempunyai dampak yatujuan zng besar pada kinerja keuangan dan bberpengaruh penting terhadap nilai penempatan posisi merk di benak pelanggan. Dalam proses penetapan harga jual suatu produk M. Suyanto (2007:123) menerangkan bahwa perusahaan hhendaknya mengikuti prosedur yang terdiri dari enam langkah pokok yaitu:

1. Memilih Sasaran Harga

2. Menetukan Permintaan

3. Memperkirakan biaya

4. Menganalisis pesaing

5. Memilih metode harga

6. Memilih harga akhir

Sedangkan menurut Tjiptono (2002:152) tujuan penetapan harga yaitu:

1. Tujuan Berorintasi pada laba

2. Tujuan berorientasi pada volume

3. Tujuan berorientasi pada citra

4. Tujuan Stabilisasi harga

5. Tujuan-tujuan lainnya

Tujuan -tujuan penetapan haarga di atas memiliki implikasi penting terhadap strategi bersaing perusahaan. Tujuan yang ditetapkan harus konsisten dengan cara yang ditempuhh perusahaan dalam menempatkan posisi relatifnya dalam persaingan

\subsection{Promosi}

Promosi merupakan suatu alat untuk memperkenalkan suatu produk yang dapat membuat konsumen merasa yakin akan produk yang ditawarkan oleh produsen. Menurut Rambat Lupiyodi ( 2013; 120) , promosi adalah suatu alat komunikasi antara perusahaan dengan konsumen dan juga sebagai alat untuk mempengaruhi konsumen dalam kegiatan pembelian atau penggunaan jasa sesuai dengan keinginan dan kebutuhannya. Dari pengertian diatas maka kegiatan promosi sangat penting dilakukan oleh perusahaan untuk memberitahukan produk ataupun jasa yang ditawarkan kepada calon konsumen bahkan dengan adanya kegiatan promosi para calon konsumen dipengaruhi untuk membeli produk dan jasa yang ditawarkan.

\subsection{Tujuan Promosi}

Menurut Tjiptono $(2002 ; 221)$ tujuan utama dari promosi adalah menginformasikan, 
mempengaruhi dan membujuk, serta mengingatkan pelanggan sasaran tentang perusahaan dan bauran pemasarannya. Secara rinci ketiga tujuan promosi tersebut dapat dijabarkan sebagai berikut.

1. Menginformasikan (informing), dapat berupa:
a. Menginformasikan pasar mengenai keberadaan suatu produk baru
b. Memperkenalkan cara pemakaian yang baru dari suatu produk
c. Menyampaikan perubahan harga kepada pasar
d. Menjelaskan cara kerja suatu produk
e. Menginformasikan jasa-jasa yang disediakan oleh perusahaan
f. Meluruskan kesan yang keliru
g. Mengurangi ketakutan atau kekhawatiran pembeli
h. Membangun citra perusahaan

2. Membujuk pelanggan sasaran (persuading) untuk:

a. Membentuk pilihan merek

b. Mengalihkan pilihan ke merek tertentu

c. Mengubah persepsi pelanggan terhadap atribut produk

d. Mendorong pembeli untuk belanja saat itu juga

e. Mendorong pembeli untuk menerima kunjungan wiraniaga (salesman)

3. Mengingatkan (reminding), dapat terdiri atas:

a. Mengingatkan pembeli bahwa produk yang bersangkutan dibutuhkan dalam waktu dekat b. Mengingatkan pembeli akan tempattempat yang mejual produk perusahaan

c. Membuat pembeli tetap ingat walaupun tidak ada kampanye iklan

d. Menjaga agar ingatan pertama pembeli jatuh pada produk perusahaan. Misalnya bila membeli ingin membeli sabun mandi, diharapkan ingatan pertamanya adalah merek lux.

Secara singkat promosi berkaitan dengan upaya untuk mengarahkan seseorang agar dapat mengenal produk perusahaan, lalu memahaminya, berubah sikap, menyukai, yakin, kemudian akhirnya membeli dan selalu ingat akan produk tersebut.

\subsection{Saluran Distribusi}

Saluran distribusi merupakan suatu cara untuk menyampaikan barang maupun jasa dari perantara keprodusen akhir. Saluran distribusi menghubungkan para pemasok dan produsen dengan pemakai akhir. Sebagus apapun sebuah produk kalau tidak tersedia di tempat yang tepat, maka tidak akan ada gunannya. Karena itu, salah satu pertimbangan utama dalam mensegmentasikan pasar dan menentukan sasaran pasar adalah dengan aksesbilitas yang baik. Menghadapi persaingan yang semakin kompetitif di dalam bisnis ritel modern, pemasar harus dapat merancang dan melaksanakan strategi pemasaran yang tepat terutama mengenai strategi saluran distribusi.

\subsection{Tingkatan Saluran Distribusi}

Terdapat beberapa tingkatan saluran distribusi dalam menyalurkan barang dan jasa yang ditujukan pada pasar konsumen. Tingkatan saluran pemasaran konsumen menurut Kotler dan Keller (2007:129), empat tingkatan saluran pemasaran tersebut adalah sebagai berikut :

1. Saluran Nol Tingkat

Produsen $\longrightarrow$ Konsumen

Disebut juga "Saluran Pemasaran Langsung", saluran ini terdiri dari produsen yang menjual langsung kepada konsumen.

2. Saluran Satu Tingkat

Produsen $\rightarrow$ Pengecer $\rightarrow$ Konsumen

Saluran satu tingkat mempunyai satu perantara penjualan. Dalam pasar konsumen, perantara itu sekaligus merupakan pengecer atau kios. Sedangkan dalam pasar industri seringkali perantara itu bertindak sebagai agen atau distributor penjualan atau makelar.

3. Saluran Dua Tingkat

Produsen $\rightarrow$ Pedagang Besar $\longrightarrow$ Pengecer $\longrightarrow$ Konsumen

Saluran dua tingkat mempunyai dua perantara penjualan. Di dalam pasar konsumen, mereka merupakan distribusi atau pedagang besar dan sekaligus pengecer atau kios. Sedangkan dalam pasar industri mereka mungkin merupakan sebuah penyalur tunggal dan penyalur industri. 


\section{Saluran Tiga Tingkat}

Produsen $\rightarrow$ Pedagang Besar $\rightarrow$ Pemborong $\rightarrow$ Pengecer $\rightarrow$ Konsumen

Saluran tiga tingkat mempunyai tiga perantara penjualan, yang terdiri dari distributor atau pedagang besar, pemborong, pengecer atau kios.

\subsection{Bauran Pemasaran}

Pengambilan keputusan dibidang pemasaran hampir selalu berkaitan dengan variabel-variabel bauran pemasaran (marketing mix). Bauran pemasaran terdiri dari apa saja yang dapat dilakukan perusahaan untuk mempengaruhi permintaan produknya. Bauran pemasaran menjadi konsep bagi aktivitas perusahaan dalam pencapaian tujuan perusahaan, dengan mengefektifkan aktivitas pemasaran. Pengertian bauran pemasaran menurut Fandy Tjiptono (2002:30) adalah seperangkat alat yang digunakan pemasar untuk membentuk karakteristik jasa yang ditawarkan kepada pelanggan.

Definisi lain yang dikemukakan oleh Kotler dan Keller (2007:17), pengertian bauran pemasaran adalah seperangkat alat pemasaran yang digunakan perusahaan untuk terus-menerus mencapai tujuan pemasarannya di pasar sasaran.

Berdasarkan beberapa definisi di atas, dapat ditarik kesimpulan bahwa bauran pemasaran merupakan unsur-unsur pemasaran yang digunakan setiap perusahaan untuk mencapai tujuan pemasarannya yang efektif, sekaligus memuaskan kebutuhan dan keinginan konsumen. Bauran pemasaran terdiri dari segala sesuatu yang dapat dilakukan perusahaan untuk mempengaruhi permintaan dari sebuah produk. Unsur-unsur bauran pemasaran menurut Kotler dan Keller (2008:17), mengklasifikasikan bauran pemasaran menjadi empat kelompok yang lebih dikenal dengan 4P yaitu :

1. Produk (Product)

Produk adalah segala sesuatu yang dapat memenuhi atau memuaskan kenutuhan dan keinginan manusia baik yang berwujud maupun yang tidak berwujud.

2. Harga (Price)

Harga adalah sejumlah uang sebagai alat tukar untuk memperoleh produk atau jasa.

3. Tempat/Saluran Distribusi (Place)

Tempat atau saluran distribusi terdiri dari seperangkat lembaga yang melakukan semua kegiatan atau fungsi yang digunakan untuk menyalurkan produk dan status pemiliknya dari produsen ke konsumen.
4. Promosi (Promotion)

Promosi adalah suatu komunikasi informasi penjualan dan pembelian, mempengaruhi konsumen, serta mengingatkan pasar sasaran yang bertujuan mengubah sikap dan tingkah laku pembelian, yang tadinya tidak mengenal sehingga menjadi pembeli dan mengingat produk tersebut.

Sesuai dengan perkembangan zaman, bauran pemasaran untuk bidang jasa menurut Tjiptono (2002:30) ditambah menjadi 3P, yaitu

\section{Orang (People)}

Semua orang yang memainkan peranan dalam penyajian jasa sehingga dapat mempengaruhi persepsi pembeli. Elemenelemen dari orang (people) adalah pegawai perusahaan, konsumen, dan konsumen lain dalam lingkungan jasa.

6. Bukti Fisik (Physical Evidence)

Merupakan suatu hal yang secara nyata turut mempengaruhi keputusan konsumen untuk membeli dan menggunakan produk/jasa yang ditawarkan. Unsur-unsur yang termasuk dalam sarana fisik antara lain lingkungan fisik, peralatan, logo, warna, dan barang lainnya yang disatukan dengan pelayanan.

7. Proses (Process)

Semua prosedur aktual, mekanisme, dan aliran aktivitas yang digunakan untuk menyampaikan jasa.

Bauran pemasaran di atas yang mulanya merupakan bauran pemasaran barang yang terdiri dari $4 \mathrm{P}$, kini diperluas lagi agar dapat digunakan dalam pemasaran jasa yang terdiri dari $7 \mathrm{P}$.

\subsection{Keputusan Pembelian}

Menurut Kotler (2007 ;279-282)

Keputusan pembelian adalah tahap dalam proses pengambilan keputusan pembeli dimana konsumen benar-benar membeli produk. Terdapat lima proses dalam pengambilan keputusan pembelian produk. Tahap-tahap ini biasa dilakukan konsumen untuk melakukan pembelian produk baru tetapi setiap konsumen juga tidak selalu menggunakan lima tahap ini secara 
keseluruhan dalam melakukan pembelian.

dijelaskan

sebagai

berikut:

Proses keputusan pembelian konsumen akan

\begin{tabular}{|c|c|c|}
\hline $\begin{array}{c}\text { Pengenalan } \\
\text { Masalah } \\
\text { Informasi }\end{array} \mapsto \begin{array}{c}\text { Evaluasi } \\
\text { Alternatif }\end{array} \mapsto \begin{array}{c}\text { Keputusan } \\
\text { Membeli }\end{array} \mapsto \begin{array}{c}\text { Perilaku } \\
\text { Sesudah } \\
\text { Pembelian }\end{array}$ \\
\hline
\end{tabular}

Gambar 2.3 Tahap-tahap pengambilan keputusan

Berikut ini merupakan penjelasan dari gambar di atas :

a. Pengenalan Masalah

Proses ini dimulai dengan pembeli mengenali suatu masalah atau kebutuhan pribadi konsumen.

b. Pencarian Informasi

Seorang konsumen yang telah dirangsang kebutuhan itu dapat atau tidak dapat mencari informasi. Sumber informasi tersebut antara lain keluarga, iklan, media masa, pengguna produk.

c. Evaluasi Alternatif

Hal tersebut berkaitan dengan bobot yang diberikan terhadap produk dengan membandingkan antara satu produk dengan produk yang lain.

d. Keputusan Membeli

Konsumen membentuk suatu niat membeli atas dasar faktor seperti pendapatan, harga, dan manfaat produk yang diharapkan.

e. Perilaku Sesudah Pembelian

Setelah membeli produk, konsumen akan mengalami tingkat kepuasan atau ketidakpuasan. Konsumen juga akan terlibat dalam tindakan sesudah pembelian pada pemasar.

\section{Metode Penelitian}

\subsection{Desain Klausalitas}

Rancangan penelitian yang dilakukan adalah penelitian deskritif yaitu mendeskripsikan hubungan antara variabel Strategi Bauran Pemasaran dan kebijakan pemerintah terhadap Keputusan Pembelian gas CNG untuk kendaraan Roda empat di kota Palembang.

\subsection{Identifikasi, Definisi Operasional Variabel}

\subsubsection{Identifikasi Variabel Penelitian}

Variabel yang digunakan dalam penelitian ini adalah:

1) Variabel Independen (X)
$>\operatorname{Produk}(\mathrm{X} 1)$

$>$ Harga (X2)

$>$ Saluran Distribusi (X3)

$>$ Promosi (X4)

2) Variabel dependen $(Y)$

$>$ Keputusan Pembelian Gas CNG untuk kendaraan

\subsubsection{Definisi Operasional Variabel}

- Variabel Bebas

1. Product (produk)

Produk dalam penelitian ini adalah gas CNG yang di gunakan untuk bahan bakar kendaraan dengan istilah BBG. Dengan indikator Kualitas Gas, Konverter, serta keunggulan nya

2. Price (harga)

Harga dalam penelitian ini adalah harga Rp 3100 / LSP yang digunakan pembeli sebagai acuan untuk membeli gas CNG yang dipakai pada kendaraan ber BBG, dimana harga jual gas lebih murah dengan harga bahan bakar minyak.

3. Place (tempat)

Tempat dalam penelitian ini adalah SPBG (Stasiun Pengisian Bahan bakar Gas) yang berada di J1 Demang Lebar Daun No 89 Palembang Sumatera Selatan.

\section{Promotion (promosi)}

Promosi adalah berbagai kegiatan perusahaan untuk mengkomunikasikan dan memperkenalkan produk pada pasar sasaran. Variabel promosi meliputi antara lain sales promotion, advertising, sales force, public relation, and direct marketing.

\section{Sumber Data}

Dalam penelitian ini terdapat dua sumber menjadi yang menjadi dasar penulisan tesis, antara lain :

1. Data primer

Data primer adalah data yang diperoleh secara langsung dari obyek yang diteliti 
dengan cara riset atau peneliti lapangan. Data primer yang dipakai dalam penelitian kali ini bersumber dari kuesioner yang disebarkan ke 80 responden pengguna $\mathrm{BBG}$ yang mengisi si SPBG Musi Gas di kota Palembang

2. Data sekunder

Data sekunder adalah data yang bukan diusahakan sendiri pengumpulannya oleh peneliti. Data sekunder dalam penelitian ini diperoleh dengan metode studi kepustakaan yaitu data yang diperoleh dari literatur yang berkaitan dengan pokok permasalahan penelitian ini.

\subsubsection{Jenis Data}

Berdasarkan bentuk dan sifatnya, data penelitian dapat dibedakan dalam dua jenis yaitu data kualitatif (yang berbentuk katakata/kalimat) dan data kuantitatif (yang berbentuk angka). Data kuantitatif dapat dikelompokkan berdasarkan cara mendapatkannya yaitu data diskrit dan data kontinum. Berdasarkan sifatnya, data kuantitatif terdiri atas data nominal, data ordinal, data interval dan data rasio.

\section{- Data Kualitatif}

Data kualitatif adalah data yang berbentuk kata-kata, bukan dalam bentuk angka. Data kualitatif diperoleh melalui berbagai macam teknik pengumpulan data misalnya wawancara, analisis dokumen, diskusi terfokus, atau observasi yang telah dituangkan dalam catatan lapangan (transkrip). Bentuk lain data kualitatif adalah gambar yang diperoleh melalui pemotretan atau rekaman video.

\section{- Data Kuantitatif}

Data kuantitatif adalah data yang berbentuk angka atau bilangan. Sesuai dengan bentuknya, data kuantitatif dapat diolah atau dianalisis menggunakan teknik perhitungan matematika atau statistika. Berdasarkan proses atau cara untuk mendapatkannya, data kuantitatif dapat dikelompokkan dalam dua bentuk yaitu sebagai berikut :

1. Data diskrit adalah data dalam bentuk angka (bilangan) yang diperoleh dengan cara membilang.

2. Data kontinum adalah data dalam bentuk angka/bilangan yang diperoleh berdasarkan hasil pengukuran. Data kontinum dapat berbentuk bilangan bulat atau pecahan tergantung jenis skala pengukuran yang digunakan.

\subsubsection{Tehnik Pengumpulan Data}

Dalam usaha pengumpulan data digunakan teknik pengumpulan data sebagai berikut:

1) Studi Kepustakaan. Yaitu penelitian yang dilakukan dengan membaca literatur seperti bukubacaan, majalahmajalah ilmiah. baik yang diperoleh dari kuliah maupunyang diperoleh dari perpustakaan dan sumber lainnya. Data yang diperolehdari cara ini merupakan data tambahan sebagai pendukung atau seringdisebut sebagai data sekunder.

2) Penelitian Lapangan. Yaitu penelitian yang dilakukan langsung kepada sumber-sumber yangterkait untuk memperoleh data tentang bentukbentuk pelayanan yang diberikan dan sikap pelanggan terhadap setiap bentuk pelayanan tersebut.

Penelitian ini dilakukan dengan menggunakan instrumen atau alat penelitian berupa :

1) Observasi langsung. Yaitu mengamati secara langsung kegiatan Pengisian BBG pada kendaraan di SPBG Musi Gas, serta data-data yang berhubungan dengan penelitian ini

2) Kuesioner. Yaitu metode yang dilaksanakan dengan pengajuan daftar pertanyaan secara tertulis kepada konsumen untuk mengetahui seberapa berpengaruhnya strategi pemsaran dan lingkungan pemerintah dalam penggunaan $\mathrm{BBG}$ pengumpulan data kuesioner dilakukan dengan cara selfadministered survey, yaitu suatu survey yang meminta responden untuk mengisi sendiri kuesioner yang diberikan

\subsubsection{Pengelolaan Dan Analisis Data}

Analisis data yang digunakan adalah analisis kuantitatif dengan menggunakan metode regresi, yang bertujuan untuk mengetahui pengaruh antara produk, harga, saluran distribusi, promosi dan kebijakan pemerintah terhadap keputusan pembelian gas untuk kendraan BBG. Data primer yang diperoleh dari lapangan akan diolah menggunakan program SPSS 20.0 for windows dengan tahapan analisa 


\section{- Uji Validitas}

Uji validitas adalah untuk menunjukan sejauh mana suatu alat pengukur itu mampu mengukur apa yang ingin diukur, maka kuesioner yang disusunnya harus mengukur apa yang ingin diukurnya (Rangkuti 2013 : 179) perhitungan uji validitas dengan bantuan SPSS 20.0

\section{- Uji Reliabilitas}

Pengujian hipotesis dalam penelitian ini meliputi analisis regresi berganda. Analisis regresi berganda digunakan untuk menguji hipotesis yang menyatakan ada pengaruh Strategi Bauran Pemasaran dengan Keputusan pembelian

Uji reliabilitas adalah suatu angka indeks yang menunjukkan konsistensi suatu alat pengukur didalam mengukur gejala yang sama (Rangkuti, 2002 : 194). Uji realibilitas dilakukan dengan menggunakan perhitungan koefisien reliabilitas yaitu $\alpha$ (Alpha) secara teoritik besarnya koefisien reliabilitas mulai dari 0.0 sampai dengan 1.0, dan semakin bear nilai $\alpha$ akan menunjukan reliabilitas yang tinggi, artinya alat test ini cukup handal untuk dipakai, sehingga akan memberikan hasil yang cukup konsisten

\section{- Analisis Regresi Linear Berganda}

Pengujian secara simultan digunakan untuk menguji signifkansi korelasi ganda adalah analisis tentang hubungan antara dua variabel atau lebih variabel bebas (independent variable) dengan satu variabel terikat (dependent variable). Dalam penelitian ini, analisis regresi ganda antara Produk (X1), Harga (X2), Saluran Distribusi (X3) dan Promosi (X4) dengan Keputusan Pembelian (Y). Analisis regresi ganda bertujuan untuk meramalkan nilai pengaruh dua atau lebih variabel bebas terhadap satu variabel terikat dengan menggunakan persamaan regresi sebagai berikut

$\mathrm{Y}=\mathrm{a}_{3}+\mathrm{b}_{1} \mathrm{X}_{1}+\mathrm{b}_{2} \mathrm{X}_{2}+\mathrm{b}_{3} \mathrm{X}_{3}+\mathrm{b}_{4} \mathrm{X}_{4}+\mathrm{e}$

Dimana :

$$
\begin{array}{ll}
\mathrm{Y} & =\text { Keputusan pembelian } \\
\mathrm{a}_{3} & =\text { Bilangan Konstanta } \\
\mathrm{b}_{1} & =\text { Koefisien regresi Produk } \\
\mathrm{b}_{2} & =\text { Koefisien regresi Harga } \\
\mathrm{b}_{3} & =\text { Koefisien regresi Saluran Distribusi } \\
\mathrm{b}_{4} & =\text { Koefisien regresi Promosi } \\
\mathrm{X}_{1} & =\text { Produk } \\
\mathrm{X}_{2} & =\text { Harga } \\
\mathrm{X}_{3} & =\text { Saluran Distribusi } \\
\mathrm{X}_{4} & =\text { Promosi } \\
\mathrm{e} & =\text { error test }
\end{array}
$$

\section{- Uji Parsial (Uji t)}

Uji t pada dasarnya menunjukkan seberapa jauh pengaruh satu variabel bebas secara individual dalam menerangkan variasi variabel terikat. Tujuan dari uji t adalah untuk menguji koefisien regresi secara individual.

\section{- Uji Serentak (Uji F)}

Uji $F$ adalah uji simultan yang digunakan untuk mengetahui pengaruh variabel dimensi atribut produk secara simultan terhadap keputusan pembelian. Tabel $F$ dilakukan untuk mengetahui pengaruh variabel bebas secara bersama-sama terhadap variabel terikat.

Kesimpulan

Kesimpulan

Berdasarkan hasil analisis dan pembahasan yang telah diuraikan pada bab sebelumnya, maka penulis menarik beberapa kesimpulan atas hasil analisis tersebut yaitu sebagai berikut:

1. Dari hasil analisis regresi yang telah dilakukan dapat disimpulkan bahwa Variabel Produk, Harga, Saluran Distribusi, dan Promosi berpengaruh signifikan terhadap keputusan pembelian Gas CNG untuk BGG di kota Palembang.

2. Dari hasil olahan data persamaan regresi antara Variabel Produk, Harga, Saluran Distribusi, dan Promosi, maka variabel yang dominan berpengaruh terhadap keputusan pembelian Gas CNG untuk BGG di kota Palembang adalah faktor saluran distribusi, hal ini dikarenakan untuk variabel saluran distribusi mempunyai nilai regresi yang terbesar jika dibandingkan dengan variabel lainnya (Produk, Harga, dan Saluran Distribusi).

\subsection{Saran-saran}

Dari hasil kesimpulan yang telah diuraikan, maka adapun saran-saran yang dapat diberikan sehubungan dengan hasil kesimpulan ini adalah sebagai berikut:

1. Disaran kepada perusahaan agar menjalankan Program Promosi ,dan edukasi Konversi BBM ke BBG untuk diselenggarakan kembali, agar image Tabung BBG berbahaya dapat hilang

2. Disarankan kepada perusahaan mengajak pada pihak-pihak yang berwenang, terutama pemerintah dan instansi terkait untuk terus menjalankan program konversi 
BBM ke BBG, untuk peningkatan dan pengaktifan SPBG di seluruh wilayah Sumatera Selatan ataupun Kota Palembang.

3. Disarankan kepada perusahaan dan peneliti selanjutnya untuk lebih memahami dan meneliti faktor-faktor lain yang belum dimasukkan dalam penelitian ini, seperti faktor kebijakan pemerintah, ketersedian Gas CNG, ketersedian conferter kit, dan ketersedian bengkel BBG di kota palembang, mengingat variabel-variabel independen hanya berpengaruh kepada variabel dependen sebesar $65.8 \%$ sedangkan sisanya sebesar $34.2 \%$ adalah faktor-faktor lain yang tidak diteliti dalam penelitian ini.

\section{DAFTAR PUSTAKA}

Buyung, Bastonoi . 2002. Analisis FaktorFaktor yang Mempengaruhi konsumen terhadap keputusan Membeli Mica Cover ( Studi Kasus Produk Mica Cover Merek T-Macks pada PT. Bumindo Perkasa Cabang Semarang ). Tesis. Universitas Diponogoro, Semarang (Tidak Dipublikasi)

Harumsari, Ratih. 2012. Perumusan Startegi Program Diversifikasi Energi Dari Bahan Bakar Minyak Ke Bahan Bakar Gas di Provinsi Jawa Barat Dengan Pendekatan Analisa SWOT Kuantitatif (Studi Kasus : Depok, Cibinong, Bogor, Bekasi). Tesis Universitas Indonesia, Jakarta (Tidak Dipublikasi)

Kartika, Erna . 2008. Analisis Faktor Eksternal yang Mempengaruhi Keputusan Membeli Mobil Toyota Avanza dan Daihatsu Xenia di Medan Tesis. Universitas Sumatera Utara, Medan

Keegan, Warren J. 2009. Manajemen Pemasaran Global. Jakarta. PT Indeks

Kotler, Philip. Amstrong. 2008. Manajemen Pemasaran. Jakarta:Penerbit Erlangga.

Kotler dan Keller. 2007. Manejemen pemasaran. Jakarta:PT INDEKS.

Lamb, Hair, McDaniel. 2001. Pemasaran. Jakarta: Salemba Empat.
Lupoyadi,Rambat. 2013, Manajemen Pemasaran Jasa. Jakarta: Salemba Empat.

Maulana, Miftah Arif, 2010, Repositioning Pertamina Melalui Program SPBU Pertamina " pasti “, Skripsi. Universitas Pembangunan Nasional "Veteran “ , Jakarta (Tidak Dipublikasi)

M.Suyanto, 2007, Marketing Strategy. Yogyakarta:Andi Offset

Natalisa, Diah, 2007. Riset Pemasaran Konsep dan Aplikasi Dalam Penelitian, Palembang: Unsri

Peraturan Walikota Palembang Nomor 19, Tahun 2009 tentang Peraturan Penggunaan Bahan Bakar Gas (BBG). 2009. PT. CNG Hilir Raya, Palembang

Purbasari, Triasgani 1997. Strategi Pemasaran Dalam Meningkatkan Volume Penjualan Pada Perusahaan Rokok PT. Djarum Kudus . Tesis. Universitas Diponogoro, Semarang (Tidak Dipublikasi)

Rangkuti, Freddy, 2013. Riser Pemasaran . Jakarta: Gramedia Pustaka Utama

Rilyadi, Achmad, 2013 . Penetapan Harga Bahan Bakar Gas Untuk Transportasi Natural Gas for Vehicle ( NGV) Dan Liquefied Natural Gas (LNG) di Indonesia. Tesis . Universitas Indonesia

Saputra Hendra, 2008. Analisis Pengaruh Strategi Bauran Pemasaran Terhadap Keputusan Pembelian Teh Celup Sariwangi oleh Konsumen Rumah Tangga di kota Medan. Tesis. Universitas Sumatera Utara, Medan (Tidak Dipublikasi)

Singgih Santoso, dan Fandi Tjiptono, Riset Pemasaran, Konsep dan Aplikasi dengan SPSS, Elek Media Komputindo, Jakarta, 2001.

Swastha, Basu, 2001. Manajemen Penjualan . Yogyakarta: BPFE

Sekaran, Uma. 2006. Metode Penelitian untuk Bisnis Edisi Keempat. Jakarta:Salemba Empat.

Tedjosaputro, Liliana, 2001. Analisis Bauran Pemasaran Kaitannya Dengan Kepuasan Konssumen Sebagai Dasar Penetapan Strategi Pemasaran Jasa Hukum (Studi Kasus Pada Kantor Notaris / PPAT Dr Liliana 
Tedjosaputra, SH. MH) Tesis.

Universitas Diponogoro, Semarang

(Tidak Dipublikasi)

Tandilintin, Yuspina, 2009. Strategi

Pemasaran Pelumas Prima XP Untuk

Mempertahankan Keunggulan

Bersaing Pada PT. Pertamina (

Persero ) Unit Pemasaran VII

Makasar. Tesis Universitas

Hasanudin. Makasr.

Tjiptono. 2002. Strategi Pemasaran.

Yogyakarta:Andi Offset

Virgiola, Serly, 2011. Pengaruh Faktor

Promotional Mix Terhadap

Peningkatan Citra Pelumas Prima XP

PT. Pertamina. Skripsi Isntitu

Pertanian Bogor. Bogor 